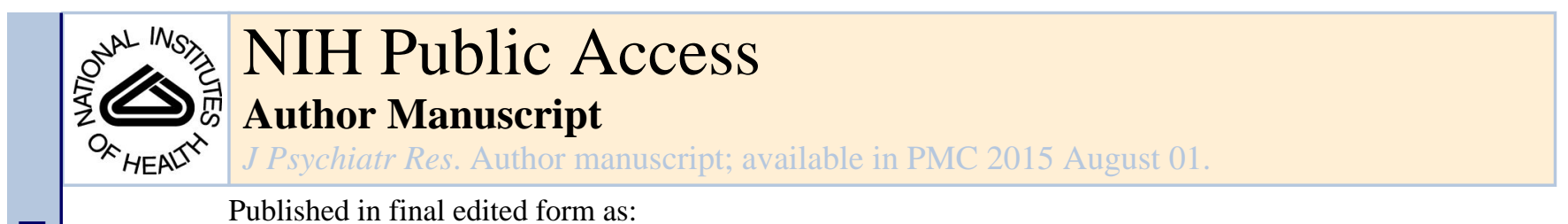

Published in final edited form as:

J Psychiatr Res. 2014 August ; 55: 77-86. doi:10.1016/j.jpsychires.2014.04.005.

\title{
The Role of Leptin, Melanocortin, and Neurotrophin System Genes on Body Weight in Anorexia Nervosa and Bulimia
}

\section{Nervosa}

\author{
Zeynep Yilmaz, $\mathrm{PhD}^{1,2}$, Allan S. Kaplan, MD FRCP(C) $)^{2,3,4}$, Arun K. Tiwari, $\mathrm{PhD}^{5}$, Robert D. \\ Levitan, MD FRCP(C) $)^{3,4,6}$, Sara Piran, $\mathbf{M S c}^{7}$, Andrew W. Bergen, $\mathbf{P h D}^{8}$, Walter H. Kaye, $\mathbf{M D}^{9}$, \\ Hakon Hakonarson, MD PhD ${ }^{10}$, Kai Wang, PhD $^{11}$, Wade H. Berrettini, MD PhD ${ }^{12}$, Harry A. \\ Brandt, MD ${ }^{13}$, Cynthia M. Bulik, PhD ${ }^{1,14}$, Steve Crawford, MD ${ }^{13}$, Scott Crow, MD ${ }^{15}$, Manfred \\ M. Fichter, MD ${ }^{16,17}$, Katherine A. Halmi, MD ${ }^{18}$, Craig L. Johnson, PhD ${ }^{19}$, Pamela K. Keel, \\ PhD $^{20}$, Kelly L. Klump, PhD ${ }^{21}$, Pierre Magistretti, MD ${ }^{22}$, James E. Mitchell, MD ${ }^{23,24}$, Michael \\ Strober, PhD $^{25}$, Laura M. Thornton, PhD ${ }^{1}$, Janet Treasure, MD ${ }^{26}$, D. Blake Woodside, MD \\ $\operatorname{FRCP}(C)^{4,27}$, Joanne Knight, PhD $^{3,4,5}$, and James L. Kennedy, MD FRCP(C) ${ }^{3,4,5}$
}

\begin{abstract}
${ }^{1}$ Department of Psychiatry, University of North Carolina at Chapel Hill, Chapel Hill, NC ${ }^{2}$ Clinical Research Department, Centre for Addiction and Mental Health, Toronto, Canada ${ }^{3}$ Institute of Medical Science, University of Toronto, Toronto, Canada ${ }^{4}$ Department of Psychiatry, University of Toronto, Toronto, Canada ${ }^{5}$ Neurogenetics Section, Centre for Addiction and Mental Health, Toronto, Canada ${ }^{6}$ Mood and Anxiety Program, Centre for Addiction and Mental Health, Toronto, Canada ${ }^{7}$ Faculty of Medicine, University of Ottawa, Ottawa, Canada ${ }^{8}$ Center for Health Sciences, SRI International, Menlo Park, CA ${ }^{9}$ Department of Psychiatry, University of California, San Diego, CA ${ }^{10}$ Joseph Stokes Jr. Research Institute, The Children's Hospital of Philadelphia, Philadelphia, PA ${ }^{11}$ Department of Psychiatry, University of Southern California, Los Angeles, CA 12 Department of Psychiatry, Center of Neurobiology and Behavior, University of Pennsylvania, Philadelphia, PA ${ }^{13}$ Department of Psychiatry, Sheppard Pratt Health System, Towson, MD ${ }^{14}$
\end{abstract}

(C) 2014 Elsevier Ltd. All rights reserved.

Corresponding author: James L. Kennedy, MD FRCP(C), Centre for Addiction and Mental Health, 250 College Street, Toronto, Ontario, M5T 1R8, Canada. Phone: (416) 5358501 x 34987; james_kennedy@camh.net.

Publisher's Disclaimer: This is a PDF file of an unedited manuscript that has been accepted for publication. As a service to our customers we are providing this early version of the manuscript. The manuscript will undergo copyediting, typesetting, and review of the resulting proof before it is published in its final citable form. Please note that during the production process errors may be discovered which could affect the content, and all legal disclaimers that apply to the journal pertain.

Contributors

Drs. Kaplan, Levitan, Yilmaz, Kennedy, Bergen, Kaye, Berrettini, Brandt, Bulik, Crawford, Crow, Fichter, Halmi, Johnson, Keel, Klump, Magistretti, Mitchell, Strober, Thornton, Treasure and Woodside were involved in the recruitment of the eating disorder cases, biospecimen collection and DNA extraction. Drs. Yilmaz, Kaplan and Kennedy designed the present study and wrote the study protocol. Dr. Tiwari assisted with the marker selection and in silico analysis. With the help of Ms. Piran, Dr. Yilmaz prepared and genotyped the DNA samples. Drs. Hakonarson and Wang provided $p$-values from the previous Price Foundation-Children's Hospital of Pennsylvania GWAS for comparison of results. Drs. Yilmaz and Knight were involved in the statistical analysis, and Dr. Yilmaz prepared the manuscript. All authors contributed to and have approved the final manuscript.

Conflict of Interest

Dr. Kennedy has received honoraria from Eli Lilly and Roche, whereas Dr. Levitan has received honorarium from Astra-Zeneca. Dr. Bergen is an employee of SRI International, and has received research, salary and travel support from the National Institutes of Health, from the Price Foundation, Ltd., and from the University of California, San Diego, through grants, study section service, and through professional service agreements. Dr. Bulik is a consultant for Shire Pharmaceuticals. Other authors have no financial interests to disclose. 
Department of Nutrition, University of North Carolina at Chapel Hill, Chapel Hill, NC ${ }^{15}$ Department of Psychiatry, University of Minnesota, Minneapolis, MN ${ }^{16}$ Department of Psychiatry, University of Munich (LMU), Munich, Germany ${ }^{17}$ Roseneck Hospital for Behavioral Medicine, Prien, Germany ${ }^{18}$ Department of Psychiatry, Weill Cornell Medical College, New York, NY ${ }^{19}$ Center for Eating Recovery, Denver, CO 20 Department of Psychology, Florida State University, Tallahassee, FL ${ }^{21}$ Department of Psychology, Michigan State University, East Lansing, MI 22 Brain Mind Institute, EPFLCH-1015 Lausanne, Switzerland ${ }^{23}$ Department of Clinical Neuroscience, University of North Dakota School of Medicine and Health Sciences, Grand Forks, ND ${ }^{24}$ Neuropsychiatric Research Institute, Fargo, ND ${ }^{25}$ Department of Psychiatry, Semel Institute for Neuroscience and Human Behavior, David Geffen School of Medicine, University of California, Los Angeles, CA ${ }^{26}$ Department of Academic Psychiatry, Kings College London, Institute of Psychiatry, London, United Kingdom ${ }^{27}$ Eating Disorders Program, Toronto General Hospital, Toronto, Canada

\section{Abstract}

Objective-Although low weight is a key factor contributing to the high mortality in anorexia nervosa (AN), it is unclear how AN patients sustain low weight compared with bulimia nervosa (BN) patients with similar psychopathology. Studies of genes involved in appetite and weight regulation in eating disorders have yielded variable findings in part due to small sample size and clinical heterogeneity. This study: (1) assessed the role of leptin, melanocortin, and neurotrophin genetic variants in conferring risk for $\mathrm{AN}$ and $\mathrm{BN}$ and (2) explored the involvement of these genes in body mass index (BMI) variations within $\mathrm{AN}$ and $\mathrm{BN}$.

Method-Our sample consisted of 745 individuals with AN without a history of BN, 245 with $\mathrm{BN}$ without a history of AN, and 321 controls. We genotyped 20 markers with known or putative function among genes selected from leptin, melanocortin, and neurotrophin systems.

Results-There were no significant differences in allele frequencies among individuals with AN, BN, and controls. AGRP rs13338499 polymorphism was associated with lowest illness-related BMI in those with AN ( $p=0.0013)$, and NTRK2 rs1042571 was associated with highest BMI in those with BN $(p=0.0018)$.

Discussion-To our knowledge, this is the first study to address the issue of clinical heterogeneity in eating disorder genetics and to explore the role of known or putatively functional markers in genes regulating appetite and weight in individuals with AN and BN. If replicated, our results may serve as an important first step toward gaining a better understanding of weight regulation in eating disorders.

\section{Keywords}

anorexia nervosa; bulimia nervosa; candidate gene association; body weight; melanocortins; neurotrophins 


\section{BACKGROUND}

Indifference to extreme weight loss and low motivation to restore normal body mass are the sine qua nons of anorexia nervosa (AN) and the primary target of initial treatment (American Psychiatric Association, 2006). As the illness is often protracted, low BMI and the avoidance of eating to restore healthy weight are primary factors influencing high morbidity and mortality that distinguish this illness. Low weight (and the permissive factors involved) are of interest for additional reasons as these are key aspects of AN; moreover, low body weight is the primary distinguishing diagnostic feature separating AN from bulimia nervosa (BN; American Psychiatric Association, 2013) and is associated with other clinical phenotypes, anxiety in particular (Dellava et al, 2010; Thornton et al, 2011).

To date, the genetic risk architecture underlying eating disorders (EDs) remains largely unexplored; however, like most other psychiatric illnesses, the heritability of EDs appears to follow a non-Mendelian pattern, suggesting that large numbers of genes spanning multiple regions of the genome are involved in susceptibility. While a number of ED candidate gene studies have investigated neurotransmitter systems involved in motivated behaviors (Hinney et al, 1997; Gorwood et al, 2002; Hu et al, 2003; Ricca et al, 2004; Nisoli et al, 2007; Sorli et al, 2008; Frieling et al, 2010), the results have been unpersuasive. Other studies that focused on regulators of appetite and weight have yet to implicate specific and replicable polymorphisms or gene-phenotype associations (Hinney et al, 1998; Vink et al, 2001; Janeckova, 2001; Quinton et al., 2004; Cellini et al, 2006; Monteleone et al, 2006;

Dardennes et al, 2007), whereas a number of genes with effects on appetite and weight regulation have yet to be examined in EDs (Table 1). Similarly, although neurotrophin system genes have also been implicated in EDs in case-control studies (Ribases et al, 2003; 2004; 2005a; 2005b; Dmitrzak-Weglarz et al, 2007; Kaplan et al, 2008; Mercader et al, 2008), a recent meta-analysis has called into question the significance the reliability of some of these findings (Brandys et al, 2013), while the other findings await replication.

Furthermore, genome-wide association studies (GWAS) of obesity have identified new genetic variants with potential implication for ED phenotypes; for instance, common variants near the melanocortin 4 receptor $(M C 4 R)$ gene have been repeatedly associated with BMI in obesity (e.g., Loos et al, 2008; Luan et al, 2009; Thorleifsson et al, 2009; Speliotes et al, 2010; Elks et al, 2010; Scherag et al, 2010; Beckers et al, 2011; Kvaloy et al, 2013); although thus far this marker has not yielded positive findings in AN (Brandys et al., 2010), it requires further investigation. $M C 4 R$ variants have also been associated with antipsychotic medication-induced weight gain (Malhotra et al, 2012; Chowdhury et al, 2013); however, the relevance of these variants with promising findings to ED phenotype variation currently remains unknown.

A complication in genetic studies of EDs is instability of the phenotype as the crossover between ED diagnoses, in particular from $\mathrm{AN}$ to $\mathrm{BN}$, is upwards of 34-36\% (Tozzi et al, 2005; Eddy et al, 2008), and most crossover occurs within five years from time of AN onset. By contrast, the BN to AN crossover is less common (Fichter and Quadflieg, 1997; Tozzi et al, 2005; Eddy et al, 2008). For this reason, clearly defining AN and BN phenotypes considering longitudinal course of illness is important to the design of genetic studies, as weight histories of $\mathrm{AN}$ and $\mathrm{BN}$ often diverge, and $\mathrm{BN}$ patients with prior $\mathrm{AN}$ histories 
usually report significantly lower current, maximum, and minimum BMIs than BN patients without histories of AN (Kaye et al, 2004); premorbid obesity is more prevalent in those with BN compared with those with AN (33.2\% vs. 4.6\%, respectively; Villarejo et al, 2012); and a higher maximum lifetime BMI may be a predictor of AN to BN crossover (Monteleone et al, 2011).

The present study had two aims: first, to investigate single nucleotide polymorphisms (SNPs) with known, or putative, functions in the leptin, melanocortin, and neurotrophin system genes in individuals with $\mathrm{AN}, \mathrm{BN}$, and healthy controls; second, to explore the role of the selected candidate genes on illness-related minimum BMI, maximum lifetime BMI, and BMI at the time of ascertainment in each clinical group (AN and BN) separately.

\section{METHODS AND MATERIALS}

\section{Sample Selection}

The main sample used for the selection of suitable cases was derived from the Price Foundation Consortium. All participants included in this collaborative initiative were carefully phenotyped, and these procedures and sample characteristics have been previously described in detail (Kaye et al, 2000; Kaye et al, 2004; Jacobs et al, 2009). The present study consisted of a subgroup of female participants who either had AN with no history of BN (AN) or BN with no history of AN (BN; Supplementary Table 1). Minimum illness duration was three years for individuals in each diagnostic group to ensure stability of ED diagnosis. The AN group included individuals with the restricting (AN-R), binge/purge and purging (combined as AN-BP) subtypes. It was ensured that the individuals classified as AN-BP had no history of $\mathrm{BN}$, i.e., regular binge eating and purging when not underweight.

Additional DNA samples from females with BN with no history of AN were selected from the Toronto Bulimia Nervosa Genetics Study (Supplementary Table 1), stored at the Centre for Addiction and Mental Health (CAMH) Neurogenetics Laboratory in Toronto, Canada. Recruitment criteria for this study closely followed those of the Price Foundation BN cases, and the details on recruitment have been published elsewhere (Yilmaz et al, 2011; Yilmaz et al, 2012). Finally, DNA samples from female controls with no psychiatric history (as assessed by a self-report checklist) were obtained from the Toronto Centre for Applied Genomics. Since the controls were not screened for EDs, we only included individuals with a BMI between $19 \mathrm{~kg} / \mathrm{m}^{2}$ and $28 \mathrm{~kg} / \mathrm{m}^{2}$ to avoid extreme weight phenotypes (Supplementary Table 1).

All aspects of this research study were reviewed and approved by the CAMH Research Ethics Board and conducted in accordance with the Helsinki Declaration as revised in 1989. Informed consent for providing genetic materials and inclusion of these materials in future collaborative studies was obtained from all individuals whose DNA samples were included in our analysis.

\section{Laboratory Methods}

Our genetic analysis focused on 11 candidate genes in the leptin (LEPR, LEP, GHRL, HRH1), melanocortin (MC3R, MC4R, AGRP, POMC), and neurotrophin (BDNF, NTRK2, 
NTRK3) systems. We pursued a targeted approach that focused on SNPs with known or putative function, as assessed by in silico analysis. This approach has a number of advantages over the tag SNP approach: first, the study of functional variants helps us make more biologically meaningful discoveries as to the effects of any genetic differences associated with the phenotype being studied; second, focusing on a small number of carefully selected loci reduces multiple testing and requires less stringent statistical correction. Two in silico tools were used: the National Institute of Environmental Health Sciences (http://snpinfo.niehs.nih.gov) and BrainArray (http:// brainarray.mbni.med.umich.edu). On average, two markers per gene were selected. Priority was given to SNPs that have been studied in EDs, and a small number of SNPs without known function were also included based on the promising findings they have yielded in EDs despite small sample size (NTRK2 rs1078947), obesity (MC4R rs17782313), antipsychotic medication-induced weight gain (MC4R rs489693 and rs8087522; Table 1).

Genomic DNA was extracted from whole blood for Price Foundation samples and from lymphocytes for Toronto BN cases and healthy controls using the high salt method (Lahiri and Nurnberger, 1991). All genotyping was performed using standard protocols for Applied Biosystems OpenArray ${ }^{\circledR}$ and $\mathrm{ViiA}^{\mathrm{TM}} 7$ platforms at $\mathrm{CAMH}$, blind to diagnosis.

\section{Statistical Analysis}

Chi-square, t-test, and analysis of variance on anthropometric, demographic, and disease characteristics across AN, BN, and controls were performed using SPSS Statistics v17 (SPSS Inc., Chicago, USA, 2008). Quality control (QC) steps prior to data analysis consisted of checking for deviations from Hardy-Weinberg Equilibrium (HWE; cutoff $p<0.01$ ), removal of SNPs with low minor allele frequency (MAF; <0.03) and low genotyping rate $(<90 \%)$, and exclusion of individuals with low genotyping rate $(<90 \%)$. For case-control analysis, genotype and ED diagnosis were treated as categorical variables. The chi-square test was performed for the case-control comparisons using PLINK (Purcell et al, 2007). Power calculations were carried out using Quanto v.1.2.4 (http://hydra.usc.edu/gxe), and we have over $90 \%$ power to detect an odds ratio as low as 1.5 (alpha=0.05, two-tailed, $\mathrm{MAF}=0.10, \log$ additive model).

For the quantitative phenotypic analysis, we investigated the role of the genetic polymorphisms on three BMI measures: BMI at recruitment (curBMI), maximum lifetime BMI (maxBMI), and lowest illness-related BMI (minBMI). Quantitative data were analyzed separately in AN and BN using linear regression in PLINK. Age, age of onset, AN subtype (for AN only) and source (Price Foundation versus Toronto; for BN only) were entered as covariates, where appropriate, and we have over $80 \%$ power to detect a mean change of 0.6 $\mathrm{kg} / \mathrm{m}^{2}$ in BMI for the AN group (alpha=0.05, two-tailed, MAF=0.10, log additive model).

We corrected for multiple testing using Single Nucleotide Polymorphism Spectral Decomposition (SNPSpD; Nyholt, 2004; Li and Ji, 2005). This method calculates the effective number of independent loci for the SNPs on the same gene using linkage disequilibrium (LD) information (Nyholt, 2004; Li and Ji, 2005). Once the effective number of independent loci was determined per gene, the adjusted alpha was calculated by dividing the uncorrected $p$-value of 0.05 by the effective number of independent SNPs. In our study, 
the effective number of independent SNPs was determined to be 18.75 , setting the adjusted $p<0.0027$. All statistical analyses were two-tailed.

\section{RESULTS}

After applying the selection criteria, $787 \mathrm{AN}$ cases, $267 \mathrm{BN}$ cases, and 322 healthy controls were included. Following QC, 42 AN cases, 22 BN cases, and one control were removed due to low genotyping rate, bringing the final sample to $745 \mathrm{AN}, 245 \mathrm{BN}$, and 321 controls. Of the AN cases, 369 had AN-R (49.5\%), whereas 376 had AN-BP (50.5\%). All AN and $128 \mathrm{BN}$ cases (52.2\%) came from the Price Foundation Consortium, and $117 \mathrm{BN}$ cases (47.8\%) came from the Toronto Bulimia Nervosa Genetics Study. Individuals removed due to low genotyping rate did not differ from those who passed QC in terms of demographic, anthropometric, and disease characteristics (results not shown).

In terms of sample characteristics (Table 2), controls were significantly older than AN and BN cases $(p<0.0001)$, whereas AN cases had a significantly lower mean curBMI compared with the other two groups $(p<0.0001)$. There were also significant differences between AN and BN groups in minBMI $(p<0.0001)$ and maxBMI $(p<0.0001)$.

We also observed a number of differences between AN-R and AN-BP subtypes. Cases in the AN-R group were younger $\left(M_{A N-R}=25.0 \pm 8.5, M_{A N-B P}=27.2 \pm 8.4, p<0.0001\right)$, weighed less at recruitment $\left(M_{A N-R}=17.85 \pm 2.79, M_{A N-B P}=18.25 \pm 2.62, p=0.042\right)$, and reported both lower $\operatorname{minBMI}$ and lower maxBMI $\left(M_{A N-R}=13.66 \pm 1.89, M_{A N-B P}=13.98 \pm 1.99, p=0.025\right.$;

$M_{A N-R}=20.86 \pm 2.42, M_{A N-B P}=21.29 \pm 2.40, p=0.013$; respectively). Age of onset for AN did not differ between subtypes $\left(M_{A N-R}=16.2 \pm 3.2, M_{A N-B P}=16.2 \pm 2.9, p=0.758\right)$. When BN cases were stratified by source, Price Foundation cases were older at recruitment $\left(M_{\text {Price }}=29.0 \pm 9.6, M_{\text {Toronto }}=25.2 \pm 6.7, p<0.0001\right)$ and had an earlier age of onset compared with Toronto cases $\left(M_{\text {Price }}=17.0 \pm 3.7, M_{\text {Toronto }}=18.0 \pm 4.2, p=0.015\right)$.

The minimum SNP genotype completion rate was $93 \%$, with the majority of the SNPs reaching over $98 \%$. None of the SNPs deviated from HWE in any of the three groups, and most of the SNPs were not correlated except for the SNPs in LEPR and MC4R, which were in moderate linkage disequilibrium ( $\mathrm{LD} ; r^{2}=0.62$ and 0.77 , respectively).

Results of the case-control comparisons are summarized in Supplementary Table 2. We did not find any evidence for differences in allele frequencies between $\mathrm{AN}$ and $\mathrm{BN}$ cases, $\mathrm{AN}$ and controls, or BN and controls. For the within-AN analysis of BMI, we entered age, age of onset of AN, and AN subtype as covariates. Although age of onset was comparable between subtypes, we chose to control for it since AN onset and weight suppression at an earlier age may act as a confounder in the analysis. Table 3 summarizes our findings involving curBMI, minBMI, and maxBMI in AN. None of the markers studied were linked to curBMI or maxBMI in AN. However, AGRP rs13338499 was significantly associated with minBMI $(p=0.0013$; Table 3 ). Table 4 presents the results of our analysis in $\mathrm{BN}$, where age, age of onset of $\mathrm{BN}$, and source were entered as covariates. We did not find a significant association between the studied markers and curBMI or minBMI. However, we observed an association between neurotrophic tyrosine kinase receptor type 2 (NTRK2) rs1042571 and maxBMI in 
BN (Table 4), with each copy of the T allele being correlated with a mean maxBMI increase over $1 \mathrm{~kg} / \mathrm{m}^{2}(p=0.0018)$.

\section{DISCUSSION}

The case-control comparisons in the present study were designed to genotype a select number of SNPs with known or putative function in the leptin, melanocortin, and neurotrophin system genes in individuals with $\mathrm{AN}, \mathrm{BN}$, and healthy controls. Despite the methodological strengths of this study in maximizing phenotypic differences between AN and $\mathrm{BN}$, we did not observe differences between the two ED groups and frequencies of genetic variants included in the analysis. Furthermore, there were no differences in allele frequencies between $\mathrm{AN}, \mathrm{BN}$, and control groups. One possible reason for this is that the control and BN sample sizes were too small and that these sample size limitations resulted in an underpowered analysis. In addition, differences among $\mathrm{AN}, \mathrm{BN}$, and control groups may not be a function of vulnerability to sustained weight suppression, and future research should focus on different gene systems and ED-related phenotypes based on different $a$ priori phenotypic hypotheses. Finally, it is possible that leptin-melanocortin-neurotrophin system genes may not confer risk for $\mathrm{AN}$ or BN.

In the AN group, $A G R P$ rs13338499 was significantly associated with minBMI. To our knowledge, although the AGRP gene has been previously associated with body weight (Bonilla et al, 2006; Li et al, 2013) and AN (Vink et al, 2001; Dardennes et al, 2007), this is the first time this particular polymorphism has been studied in reference to BMI and EDs, and it is not in LD with any other $A G R P$ locus previously investigated in EDs. This finding is intriguing on mechanistic and translational grounds, given that the Agrp knockout mouse is one of the earliest animal models of obesity and AGRP administration ameliorates selfstarvation and hyperactivity in rats (Kas et al, 2003; Hillebrand et al, 2006). In the case of acute AN, plasma AGRP levels are reported to be elevated (Moriya et al, 2006; Merle et al, 2011) and inversely correlated with BMI (Moriya et al, 2006). According to in silico analysis, rs13338499 is a putative transcription factor-binding site, and, since it is located upstream of the $A G R P$ gene it may play a regulatory role. Considering the key orexigenic role AGRP plays through the hypothalamus, this finding further highlights the potential importance of the melanocortin system in weight regulation.

In the BN group, NTRK2 rs1078947 T allele was associated with higher maxBMI, a finding that is not in agreement with a previous report that found the $\mathrm{C}$ allele to be linked to a higher maxBMI in AN (Ribases et al, 2005b). A few possible explanations exist for this discrepancy. First, since rs1078947 did not yield any significant association with any of the three BMI measures in our 745 AN cases, the association reported in the first study might have been a false positive related to small sample size $(\mathrm{N}=83)$. Second, it is possible that the AN group in the previous study may have included individuals with a history of BN, which may have led to the difference in the reported findings due to phenotypic heterogeneity. Furthermore, since the previous study was conducted using Spanish ancestry cases, the results could also be ancestry-specific. Replication studies are needed to understand the relationship between this marker and BMI in EDs. Via its expression in the hypothalamus, NTRK2 is involved in appetite and weight regulation; furthermore, peripheral and central 
administrations of NTRK2 agonists lead to appetite and weight suppression in animals and reduced obesity in $B d n f$ knockout mice (Xu et al, 2003). This marker is not predicted to have function in silico and was included in our study due to a previous preliminary association reported in AN (Ribases et al, 2005b), and our results combined with the previous findings further highlight the need for functional studies involving rs1078947.

Since a GWAS has been performed by the Price Foundation on the larger AN sample (N=1033; Wang et al, 2011), we compared our results with the GWAS $p$-values for the SNPs included in our study. Out of the 20 SNPs analyzed in this study, only six overlapped with the GWAS, none of which was in the top 100 hits in the GWAS case-control analysis. It is also important to note that the GWAS included AN-R cases with and without BN history and did not look at quantitative traits such as BMI.

Despite the significant methodological strengths of this study, a number of limitations also merit consideration. For instance, controls were significantly older than $\mathrm{AN}$ and $\mathrm{BN}$ cases. However, it can be argued that the older age of the controls does not pose a risk to our findings since DNA sequence is independent of age. Another possible shortcoming involving controls is the lack of ED-specific screening; however, considering the low prevalence of EDs and that the $\mathrm{AN}$ and $\mathrm{BN}$ groups are enriched for any genetic risk factor for EDs, this is a conservative bias. We also did not have any lifetime BMI measures for controls, and although we only included controls individuals within a certain BMI range, we cannot rule out history of obesity or underweight in this group. In the case of the ED groups, although AN sample size was one of the largest in ED candidate gene studies, BN and control samples were smaller, which may have reduced statistical power. Although all individuals included in the study were of European ancestry, we did not genotype ancestry informative markers to control for population substructures. Finally, although we believe that one of the strengths of this study is the utilization of functional variants, genotyping a small number of SNPs and not using tag SNPs could be another criticism; it is possible that the risk loci for EDs located in these candidate genes are outside of the markers selected and that a tag SNP approach could provide better coverage of the genes.

If replicated, the present findings may have translational implications. For example, AGRP is the inverse agonist of melanocortins, and data suggest that melanocortin signaling may play a role in the regulation of circulating cholesterol: in rodents, inhibition of melanocortin system in the central nervous system leads to an increase in high-density lipoprotein cholesterol in a manner independent of food intake or body weight (Perez-Tilve et al, 2010). Interestingly, the top hit in the recent Price Foundation AN high-throughput sequencing study was in the EPHX2 gene, known to influence cholesterol function (Scott-Van Zeeland et al, 2013). Considering that patients with AN often present with elevated cholesterol levels (Ohwada et al, 2006; Matzkin et al, 2006; Rigaud et al, 2009; Jauregui-Garrido et al, 2012), this clinical abnormality could be at least partially a sign of a disruption in the melanocortin system. Furthermore, future research on the possible use of AGRP and exogenous MC4R competitive antagonists in the treatment of AN is needed. Our results also suggest a possible role for NTRK2 receptor agonists for individuals with $\mathrm{BN}$ who are overweight or obese. BDNF is the natural NTRK2 agonist, and we are not aware of any clinical studies investigating $\mathrm{BDNF}$ administration in $\mathrm{BN}$ or obesity. Interestingly, $\mathrm{N}$-acetylserotonin, 
endogenous chemical intermediate of melatonin and serotonin, has been shown to mediate the antidepressive effects of selective serotonin reuptake inhibitors (SSRIs) through NTRK2 agonism (Jang et al, 2010). Considering that fluoxetine is approved for the treatment of BN and leads to a reduction in binge eating and purging (American Psychiatric Association, 2006), our findings are in line with the clinical evidence for SSRI use in the treatment of $\mathrm{BN}$, and if replicated, these results may provide an alternate, non-serotonergic mechanism of action of SSRIs in BN through neurotrophin agonism.

\section{Supplementary Material}

Refer to Web version on PubMed Central for supplementary material.

\section{Acknowledgments}

The authors would like to thank the individuals who contributed DNA samples for genetic research, Ms. Sarah Gagliano for her assistance with statistical analysis, Ms. Natalie Freeman, Ms. Maria Tampakeras and Mr. Sajid Shaikh for their contributions to DNA preparation, and Ms. Misti Dowell for her help with the shipment of Price Foundation DNA samples.

Role of Funding Source

The present study was funded by research grants from the Ontario Mental Health Foundation (awarded to Drs. Kaplan and Levitan) and Province of Ontario Academic Health Science Centres Academic Funding Plan Innovation Fund (awarded to Drs. Kaplan and Kennedy). Dr. Yilmaz was funded by a Canadian Institutes of Health Research Doctoral Research Award and is currently supported by the National Institutes of Health (NIH) Grant T32MH076694 (PI: Bulik). Dr. Tiwari is supported by the Brain \& Behavior Research Foundation Young Investigator Award. None of these funding agencies had any influence on the design or results of the study.

\section{REFERENCES}

American Psychiatric Association. Diagnostic and statistical manual of mental disorders. fifth edition.. Author; Washington DC: 2013.

American Psychiatric Association. Treatment of patients with eating disorders. American Journal of Psychiatry (third edition.). 2006; 163:4-54. [PubMed: 16925191]

Ando T, Komaki G, Naruo T, Okabe K, Takii M, Kawai K, Konjiki F, Takei M, Oka T, Takeuchi K. Possible role of preproghrelin gene polymorphisms in susceptibility to bulimia nervosa. American Journal of Medical Genetics Part B: Neuropsychiatric Genetics. 2006; 141:929-934.

Beckers S, Zegers D, de Freitas F, Mertens IL, Van Gaal LF, Van Hul W. Association study of MC4R with complex obesity and replication of the rs 17782313 association signal. Molecular Genetics and Metabolism. 2011; 103:71-75. [PubMed: 21303735]

Bonilla C, Panguluri RK, Taliaferro-Smith L, Argyropoulos G, Chen G, Adeyemo AA, Amoah A, Owusu S, Acheampong J, Agyenim-Boateng K, Eghan BA, Oli J, Okafor G, Abbiyesuku F, Johnson T, Rufus T, Fasanmade O, Chen Y, Collins FS, Dunston GM, Rotimi C, Kittles RA. Agouti-related protein promoter variant associated with leanness and decreased risk for diabetes in West Africans. International Journal of Obesity (London). 2006; 30:715-721.

Brandys MK, Kas MJ, van Elburg AA, Ophoff R, Slof-Op't Landt MC, Middeldorp CM, Boomsma DI, van Furth EF, Slagboom PE, Adan RA. The Val66Met polymorphism of the BDNF gene in anorexia nervosa: New data and a meta-analysis. World Journal of Biological Psychiatry. 2013; 14:441-51. [PubMed: 21936709]

Brandys MK1, van Elburg AA, Loos RJ, Bauer F, Hendriks J, van der Schouw YT, Adan RA. Are recently identified genetic variants regulating BMI in the general population associated with anorexia nervosa? American Journal of Medical Genetics Part B: Neuropsychiatric Genetics. 2010; 153:695-699.

Cellini E, Nacmias B, Brecelj-Anderluh M, Badia-Casanovas A, Bellodi L, Boni C, Di Bella D, Estivill X, Fernandez-Aranda F, Foulon C, Friedel S, Gabrovsek M, Gorwood P, Gratacos M, 
Guelfi J, Hebebrand J, Hinney A, Holliday J, Hu X, Karwautz A, Kipman A, Komel R, Rotella CM, Ribases M, Ricca V, Romo L, Tomori M, Treasure J, Wagner G, Collier DA, Sorbi S, EC Framework V. 'Factors in Healthy Eating' consortium. Case-control and combined family trios analysis of three polymorphisms in the ghrelin gene in European patients with anorexia and bulimia nervosa. Psychiatric Genetics. 2006; 16:51-52. [PubMed: 16538179]

Chiaruttini C, Vicario A, Li Z, Baj G, Braiuca P, Wu Y, Lee FS, Gardossi L, Baraban JM, Tongiorgi E. Dendritic trafficking of BDNF mRNA is mediated by translin and blocked by the G196A (Val66Met) mutation. Proceedings of the National Academy of Sciences. 2009; 106:16481-16486.

Chowdhury NI, Tiwari AK, Souza RP, Zai CC, Shaikh SA, Chen S, Liu F, Lieberman JA, Meltzer HY, Malhotra AK, Kennedy JL, Muller DJ. Genetic association study between antipsychoticinduced weight gain and the melanocortin-4 receptor gene. The Pharmacogenomics Journal. 2013; 13:272-279. [PubMed: 22310352]

Dardennes RM, Zizzari P, Tolle V, Foulon C, Kipman A, Romo L, Iancu-Gontard D, Boni C, Sinet PM, Therese Bluet M, Estour B, Mouren MC, Guelfi JD, Rouillon F, Gorwood P, Epelbaum J. Family trios analysis of common polymorphisms in the obestatin/ghrelin, BDNF and AGRP genes in patients with anorexia nervosa: Association with subtype, body-mass index, severity and age of onset. Psychoneuroendocrinology. 2007; 32:106-113. [PubMed: 17197106]

de Krom M, Bakker SC, Hendriks J, van Elburg A, Hoogendoorn M, Verduijn W, Sinke R, Kahn R, Adan RA. Polymorphisms in the brain-derived neurotrophic factor gene are not associated with either anorexia nervosa or schizophrenia in Dutch patients. Psychiatric Genetics. 2005a; 15:81. [PubMed: 15900221]

de Krom M, de Rijke CE, Hendriks J, van Engeland H, van Elburg AA, Adan RA. Mutation analysis of the agouti related protein promoter region and the melanocortin-3 receptor in anorexia nervosa patients. Psychiatric Genetics. 2005b; 15:237. [PubMed: 16314751]

Dellava JE, Thornton LM, Hamer RM, Strober M, Plotnicov K, Klump KL, Brandt H, Crawford S, Fichter MM, Halmi KA, Jones I, Johnson C, Kaplan AS, Lavia M, Mitchell J, Rotondo A, Treasure J, Woodside DB, Berrettini WH, Kaye WH, Bulik CM. Childhood anxiety associated with low BMI in women with anorexia nervosa. Behaviour Research and Therapy. 2010; 48:60 67. [PubMed: 19822312]

Dmitrzak-Weglarz M, Skibinska M, Slopien A, Szczepankiewicz A, Rybakowski F, Kramer L, Hauser J, Rajewski A. BDNF Met66 allele is associated with anorexia nervosa in the polish population. Psychiatric Genetics. 2007; 17:245-246. [PubMed: 17621170]

Eddy KT, Dorer DJ, Franko DL, Tahilani K, Thompson-Brenner H, Herzog DB. Diagnostic crossover in anorexia nervosa and bulimia nervosa: implications for DSM-V. American Journal of Psychiatry. 2008; 165:245-250. [PubMed: 18198267]

Elks CE, Loos RJ, Sharp SJ, Langenberg C, Ring SM, Timpson NJ, Ness AR, Davey Smith G, Dunger DB, Wareham NJ, Ong KK. Genetic markers of adult obesity risk are associated with greater early infancy weight gain and growth. PLoS Medicine. 2010; 7:e1000284. [PubMed: 20520848]

Feng N, Young SF, Aguilera G, Puricelli E, Adler-Wailes DC, Sebring NG, Yanovski JA. Cooccurrence of two partially inactivating polymorphisms of MC3R is associated with pediatriconset obesity. Diabetes. 2005; 54:2663-2667. [PubMed: 16123355]

Fichter MM, Quadflieg N. Six-year course of bulimia nervosa. International Journal of Eating Disorders. 1997; 22:361-384. [PubMed: 9356885]

Frieling H, Romer KD, Scholz S, Mittelbach F, Wilhelm J, De Zwaan M, Jacoby GE, Kornhuber J, Hillemacher T, Bleich S. Epigenetic dysregulation of dopaminergic genes in eating disorders. International Journal of Eating Disorders. 2010; 43:577-583. [PubMed: 19728374]

Gorwood P, Ades J, Bellodi L, Cellini E, Collier DA, Di Bella D, Di Bernardo M, Estivill X, Fernandez-Aranda F, Gratacos M, Hebebrand J, Hinney A, Hu X, Karwautz A, Kipman A, Mouren-Simeoni MC, Nacmias B, Ribases M, Remschmidt H, Ricca V, Rotella CM, Sorbi S, Treasure J, EC Framework V. 'Factors in Healthy Eating' consortium. The 5-HT(2A) -1438G/A polymorphism in anorexia nervosa: A combined analysis of 316 trios from six European centres. Molecular Psychiatry. 2002; 7:90-94. [PubMed: 11803452]

Hillebrand JJ, Kas MJ, Scheurink AJ, van Dijk G, Adan RA. AgRP(83-132) and SHU9119 differently affect activity-based anorexia. European Neuropsychopharmacology. 2006; 16:403-412. [PubMed: 16360312] 
Hinney A, Becker I, Heibult O, Nottebom K, Schmidt A, Ziegler A, Mayer H, Siegfried W, Blum WF, Remschmidt H, Hebebrand J. Systematic mutation screening of the pro-opiomelanocortin gene: Identification of several genetic variants including three different insertions, one nonsense and two missense point mutations in probands of different weight extremes. The Journal of Clinical Endocrinology and Metabolism. 1998; 83:3737-3741. [PubMed: 9768693]

Hinney A, Ziegler A, Nothen MM, Remschmidt H, Hebebrand J. 5-HT2A receptor gene polymorphisms, anorexia nervosa, and obesity. Lancet. 1997; 350:1324-1325. [PubMed: 9357428]

Hu X, Giotakis O, Li T, Karwautz A, Treasure J, Collier DA. Association of the 5-HT2C gene with susceptibility and minimum body mass index in anorexia nervosa. Neuroreport. 2003; 14:781-783. [PubMed: 12858032]

Jacobs MJ, Roesch S, Wonderlich SA, Crosby R, Thornton L, Wilfley DE, Berrettini WH, Brandt H, Crawford S, Fichter MM, Halmi KA, Johnson C, Kaplan AS, Lavia M, Mitchell JE, Rotondo A, Strober M, Woodside DB, Kaye WH, Bulik CM. Anorexia nervosa trios: behavioral profiles of individuals with anorexia nervosa and their parents. Psychol Med. 2009; 39:451-461. [PubMed: 18578898]

Janas-Kozik M, Stachowicz M, Mazurek U, Zajdel A, Wilczok A, Krupka-Matuszczyk I, Rybakowski JK. Preliminary study of the expression of genes connected with the orexigenic and anorexigenic system using microarray technique in anorexia nervosa. Neuropsychobiology. 2008; 57:116-120. [PubMed: 18552512]

Janeckova R. The role of leptin in human physiology and pathophysiology. Physiological Research. 2001; 50:443-459. [PubMed: 11702849]

Jang SW, Liu X, Pradoldej S, Tosini G, Chang Q, Iuvone PM, Ye K. N-acetylserotonin activates TrkB receptor in a circadian rhythm. Proceedings of the National Academy of Sciences. 2010; 107:3876-3881.

Jauregui-Garrido B, Bolanos-Rios P, Santiago-Fernandez MJ, Jauregui-Lobera I. Lipid profile and cardiovascular risk in anorexia nervosa; the effect of nutritional treatment. Nutrición Hospitalaria. 2012; 27:908-913. [PubMed: 23114953]

Kaplan AS, Levitan RD, Yilmaz Z, Davis C, Tharmalingam S, Kennedy JL. A DRD4/BDNF genegene interaction associated with maximum BMI in women with bulimia nervosa. International Journal of Eating Disorders. 2008; 41:22-28. [PubMed: 17922530]

Kas MJ, van Dijk G, Scheurink AJ, Adan RA. Agouti-related protein prevents self-starvation. Molecular Psychiatry. 2003; 8:235-240. [PubMed: 12610657]

Kaye WH, Devlin B, Barbarich N, Bulik CM, Thornton L, Bacanu SA, Fichter MM, Halmi KA, Kaplan AS, Strober M, Woodside DB, Bergen AW, Crow S, Mitchell J, Rotondo A, Mauri M, Cassano G, Keel P, Plotnicov K, Pollice C, Klump KL, Lilenfeld LR, Ganjei JK, Quadflieg N, Berrettini WH. Genetic analysis of bulimia nervosa: Methods and sample description. International Journal of Eating Disorders. 2004; 35:556-570. [PubMed: 15101071]

Kaye WH, Lilenfeld LR, Berrettini WH, Strober M, Devlin B, Klump KL, Goldman D, Bulik CM, Halmi KA, Fichter MM, Kaplan A, Woodside DB, Treasure J, Plotnicov KH, Pollice C, Rao R, McConaha CW. A search for susceptibility loci for anorexia nervosa: Methods and sample description. Biological Psychiatry. 2000; 47:794-803. [PubMed: 10812038]

Kindler J, Bailer U, de Zwaan M, Fuchs K, Leisch F, Grun B, Strnad A, Stojanovic M, Windisch J, Lennkh-Wolfsberg C, El-Giamal N, Sieghart W, Kasper S, Aschauer H. No association of the neuropeptide Y (Leu7Pro) and ghrelin gene (Arg51Gln, Leu72Met, Gln90Leu) single nucleotide polymorphisms with eating disorders. Nordic Journal of Psychiatry. 2011; 65:203-207. [PubMed: 21047193]

Kvaloy K, Kulle B, Romundstad P, Holmen TL. Sex-specific effects of weight-affecting gene variants in a life course perspective-the HUNT study, Norway. International Journal of Obesity (London. 2013; 37:1221-1229.

Lahiri DK, Nurnberger JI Jr. A rapid non-enzymatic method for the preparation of HMWDNA from blood for RFLP studies. Nucleic Acids Research. 1991; 19:5444. [PubMed: 1681511]

Li J, Ji L. Adjusting multiple testing in multilocus analyses using the eigenvalues of a correlation matrix. Heredity. 2005; 95:221-227. [PubMed: 16077740] 
Li P, Tiwari HK, Lin WY, Allison DB, Chung WK, Leibel RL, Yi N, Liu N. Genetic association analysis of 30 genes related to obesity in a European American population. International Journal of Obesity (London). Jul 31.2013 doi: 10.1038/ijo.2013.140.

Loos RJ, Lindgren CM, Li S, Wheeler E, Zhao JH, Prokopenko I, Inouye M, Freathy RM, Attwood AP, Beckmann JS, Berndt SI, Prostate, Lung, Colorectal, and Ovarian (PLCO) Cancer Screening Trial; Jacobs KB, Chanock SJ, Hayes RB, Bergmann S, Bennett AJ, Bingham SA, Bochud M, Brown M, Cauchi S, Connell JM, Cooper C, Smith GD, Day I, Dina C, De S, Dermitzakis ET, Doney AS, Elliott KS, Elliott P, Evans DM, Sadaf Farooqi I, Froguel P, Ghori J, Groves CJ, Gwilliam R, Hadley D, Hall AS, Hattersley AT, Hebebrand J, Heid IM, KORA; Lamina C, Gieger C, Illig T, Meitinger T, Wichmann HE, Herrera B, Hinney A, Hunt SE, Jarvelin MR, Johnson T, Jolley JD, Karpe F, Keniry A, Khaw KT, Luben RN, Mangino M, Marchini J, McArdle WL, McGinnis R, Meyre D, Munroe PB, Morris AD, Ness AR, Neville MJ, Nica AC, Ong KK, O'Rahilly S, Owen KR, Palmer CN, Papadakis K, Potter S, Pouta A, Qi L, Nurses' Health Study; Randall JC, Rayner NW, Ring SM, Sandhu MS, Scherag A, Sims MA, Song K, Soranzo N, Speliotes EK, Diabetes Genetics Initiative; Syddall HE, Teichmann SA, Timpson NJ, Tobias JH, Uda M, SardiNIA Study; Vogel CI, Wallace C, Waterworth DM, Weedon MN, Wellcome Trust Case Control Consortium; Willer CJ, FUSION. Wraight, Yuan X, Zeggini E, Hirschhorn JN, Strachan DP, Ouwehand WH, , Caulfield MJ, Samani NJ, Frayling TM, Vollenweider P, Waeber G, Mooser V, Deloukas P, McCarthy MI, Wareham NJ, Barroso I, Luan J, Kerner B, Zhao JH, Loos RJ, Sharp SJ, Muthen BO, Wareham NJ. A multilevel linear mixed model of the association between candidate genes and weight and body mass index using the framingham longitudinal family data. BMC Proceedings. 2009; 3(Suppl 7):S115. [PubMed: 20017980]

Malhotra AK, Correll CU, Chowdhury NI, Muller DJ, Gregersen PK, Lee AT, Tiwari AK, Kane JM, Fleischhacker WW, Kahn RS, Ophoff RA, Meltzer HY, Lencz T, Kennedy JL. Association between common variants near the melanocortin 4 receptor gene and severe antipsychotic druginduced weight gain. Archives of General Psychiatry. 2012; 69:904-912. [PubMed: 22566560]

Matzkin VB, Geissler C, Coniglio R, Selles J, Bello M. Cholesterol concentrations in patients with anorexia nervosa and in healthy controls. International Journal of Psychiatric Nursing Research. 2006; 11:1283-1293. [PubMed: 16459892]

Mercader JM, Saus E, Agüera Z, Bayés M, Boni C, Carreras A, Cellini E, de Cid R, Dierssen M, Escaramís G, Fernández-Aranda F, Forcano L, Gallego X, González JR, Gorwood P, Hebebrand J, Hinney A, Nacmias B, Puig A, Ribasés M, Ricca V, Romo L, Sorbi S, Versini A, Gratacòs M, Estivill X. Association of NTRK3 and its interaction with NGF suggest an altered cross-regulation of the neurotrophin signaling pathway in eating disorders. Human Molecular Genetics. 2008; 17:1234-1244. [PubMed: 18203754]

Merle JV1, Haas V, Burghardt R, Döhler N, Schneider N, Lehmkuhl U, Ehrlich S. Agouti-related protein in patients with acute and weight-restored anorexia nervosa. Psychological Medicine. 2011; 41:2183-2192. [PubMed: 21426605]

Monteleone P, Di Genio M, Monteleone AM, Di Filippo C, Maj M. Investigation of factors associated to crossover from anorexia nervosa restricting type (ANR) and anorexia nervosa binge-purging type (ANBP) to bulimia nervosa and comparison of bulimia nervosa patients with or without previous ANR or ANBP. Comprehensive Psychiatry. 2011; 52:56-62. [PubMed: 21220066]

Monteleone P, Tortorella A, Castaldo E, Di Filippo C, Maj M. No association of the Arg51Gln and Leu72Met polymorphisms of the ghrelin gene with anorexia nervosa or bulimia nervosa. Neuroscience Letters. 2006a; 398:325-327. [PubMed: 16472909]

Monteleone P, Tortorella A, Castaldo E, Di Filippo C, Maj M. The Leu72Met polymorphism of the ghrelin gene is significantly associated with binge eating disorder. Psychiatric Genetics. 2007; 17:13-16. [PubMed: 17167339]

Monteleone P, Zanardini R, Tortorella A, Gennarelli M, Castaldo E, Canestrelli B, Maj M. The 196G/A (Val66Met) polymorphism of the BDNF gene is significantly associated with binge eating behavior in women with bulimia nervosa or binge eating disorder. Neuroscience Letters $2006 \mathrm{~b}$. 2006b; 406:133-137.

Moriya J, Takimoto Y, Yoshiuchi K, Shimosawa T, Akabayashi A. Plasma agouti-related protein levels in women with anorexia nervosa. Psychoneuroendocrinology. 2006; 31:1057-1061. [PubMed: 16904835] 
Nisoli E, Brunani A, Borgomainerio E, Tonello C, Dioni L, Briscini L, Redaelli G, Molinari E, Cavagnini F, Carruba MO. D2 dopamine receptor (DRD2) gene Taq1A polymorphism and the eating-related psychological traits in eating disorders (anorexia nervosa and bulimia) and obesity. Eating and Weight Disorders. 2007; 12:91-96. [PubMed: 17615493]

Nyholt DR. A simple correction for multiple testing for single-nucleotide polymorphisms in linkage disequilibrium with each other. American Journal of Human Genetics. 2004; 74:765-769. [PubMed: 14997420]

Ohwada R, Hotta M, Oikawa S, Takano K. Etiology of hypercholesterolemia in patients with anorexia nervosa. International Journal of Eating Disorders. 2006; 39:598-601. [PubMed: 16791856]

Perez-Tilve D, Hofmann SM, Basford J, Nogueiras R, Pfluger PT, Patterson JT, Grant E, WilsonPerez HE, Granholm NA, Arnold M, Trevaskis JL, Butler AA, Davidson WS, Woods SC, Benoit SC, Sleeman MW, DiMarchi RD, Hui DY, Tschop MH. Melanocortin signaling in the CNS directly regulates circulating cholesterol. Nature Neuroscience. 2010; 13:877-882.

Purcell S, Neale B, Todd-Brown K, Thomas L, Ferreira MA, Bender D, Maller J, Sklar P, de Bakker PI, Daly MJ, Sham PC. PLINK: A tool set for whole-genome association and population-based linkage analyses. American Journal of Human Genetics. 2007; 81:559-575. [PubMed: 17701901]

Quinton ND, Meechan DW, Brown K, Eastwood H, Blakemore AI. Single nucleotide polymorphisms in the leptin receptor gene: Studies in anorexia nervosa. Psychiatric Genetics. 2004; 14:191-194. [PubMed: 15564891]

Ribases M, Gratacos M, Armengol L, de Cid R, Badia A, Jimenez L, Solano R, Vallejo J, Fernandez $\mathrm{F}$, Estivill X. Met66 in the brain-derived neurotrophic factor (BDNF) precursor is associated with anorexia nervosa restrictive type. Molecular Psychiatry. 2003; 8:745-751. [PubMed: 12888803]

Ribases M, Gratacos M, Badia A, Jimenez L, Solano R, Vallejo J, Fernandez-Aranda F, Estivill X. Contribution of NTRK2 to the genetic susceptibility to anorexia nervosa, harm avoidance and minimum body mass index. Molecular Psychiatry. 2005b; 10:851-860. [PubMed: 15838534]

Ribases M, Gratacos M, Fernandez-Aranda F, Bellodi L, Boni C, Anderluh M, Cavallini MC, Cellini E, Di Bella D, Erzegovesi S, Foulon C, Gabrovsek M, Gorwood P, Hebebrand J, Hinney A, Holliday J, Hu X, Karwautz A, Kipman A, Komel R, Nacmias B, Remschmidt H, Ricca V, Sorbi S, Wagner G, Treasure J, Collier DA, Estivill X. Association of BDNF with anorexia, bulimia and age of onset of weight loss in six European populations. Human Molecular Genetics. 2004; 13:1205-1212. [PubMed: 15115760]

Ribases M, Gratacos M, Fernandez-Aranda F, Bellodi L, Boni C, Anderluh M, Cristina Cavallini M, Cellini E, Di Bella D, Erzegovesi S, Foulon C, Gabrovsek M, Gorwood P, Hebebrand J, Hinney A, Holliday J, Hu X, Karwautz A, Kipman A, Komel R, Nacmias B, Remschmidt H, Ricca V, Sorbi S, Tomori M, Wagner G, Treasure J, Collier DA, Estivill X. Association of BDNF with restricting anorexia nervosa and minimum body mass index: A family-based association study of eight European populations. European Journal of Human Genetics. 2005; 13:428-434. [PubMed: 15657604]

Ricca V, Nacmias B, Boldrini M, Cellini E, di Bernardo M, Ravaldi C, Tedde A, Bagnoli S, Placidi GF, Rotella CM, Sorbi S. Psychopathological traits and 5-HT2A receptor promoter polymorphism $(-1438 \mathrm{G} / \mathrm{A})$ in patients suffering from anorexia nervosa and bulimia nervosa. Neuroscience Letters. 2004; 365:92-96. [PubMed: 15245785]

Rigaud D, Tallonneau I, Verges B. Hypercholesterolaemia in anorexia nervosa: Frequency and changes during refeeding. Diabetes and Metabolism. 2009; 35:57-63. [PubMed: 19101189]

Scherag A, Dina C, Hinney A, Vatin V, Scherag S, Vogel CI, Muller TD, Grallert H, Wichmann HE, Balkau B, Heude B, Jarvelin MR, Hartikainen AL, Levy-Marchal C, Weill J, Delplanque J, Korner A, Kiess W, Kovacs P, Rayner NW, Prokopenko I, McCarthy MI, Schafer H, Jarick I, Boeing H, Fisher E, Reinehr T, Heinrich J, Rzehak P, Berdel D, Borte M, Biebermann H, Krude H, Rosskopf D, Rimmbach C, Rief W, Fromme T, Klingenspor M, Schurmann A, Schulz N, Nothen MM, Muhleisen TW, Erbel R, Jockel KH, Moebus S, Boes T, Illig T, Froguel P, Hebebrand J, Meyre D. Two new loci for body-weight regulation identified in a joint analysis of genome-wide association studies for early-onset extreme obesity in french and german study groups. PLoS Genetics. 2010; 6:e1000916. [PubMed: 20421936]

Scott-Van Zeeland AA, Bloss CS, Tewhey R, Bansal V, Torkamani A, Libiger O, Duvvuri V, Wineinger N, Galvez L, Darst BF, Smith EN, Carson A, Pham P, Phillips T, Villarasa N, Tisch R, 
Zhang G, Levy S, Murray S, Chen W, Srinivasan S, Berenson G, Brandt H, Crawford S, Crow S, Fichter MM, Halmi KA, Johnson C, Kaplan AS, La Via M, Mitchell JE, Strober M, Rotondo A, Treasure J, Woodside DB, Bulik CM, Keel P, Klump KL, Lilenfeld L, Plotnicov K, Topol EJ, Shih PB, Magistretti P, Bergen AW, Berrettini W, Kaye W, Schork NJ. Evidence for the role of EPHX2 gene variants in anorexia nervosa. Molecular Psychiatry. Sep 3.20132013 doi: 10.1038/mp.2013.91.

Sorli JV, Frances F, Gonzalez JI, Guillen M, Portoles O, Sabater A, Coltell O, Corella D. Impact of the $-1438 \mathrm{G}>$ a polymorphism in the serotonin $2 \mathrm{~A}$ receptor gene on anthropometric profile and obesity risk: A case-control study in a Spanish Mediterranean population. Appetite. 2008; 50:260-265. [PubMed: 17804117]

Speliotes EK, Willer CJ, Berndt SI, Monda KL, Thorleifsson G, Jackson AU, Allen HL, Lindgren CM, Luan J, Magi R, Randall JC, Vedantam S, Winkler TW, Qi L, Workalemahu T, Heid IM, Steinthorsdottir V, Stringham HM, Weedon MN, Wheeler E, Wood AR, Ferreira T, Weyant RJ, Segre AV, Estrada K, Liang L, Nemesh J, Park JH, Gustafsson S, Kilpelainen TO, Yang J, Bouatia-Naji N, Esko T, Feitosa MF, Kutalik Z, Mangino M, Raychaudhuri S, Scherag A, Smith AV, Welch R, Zhao JH, Aben KK, Absher DM, Amin N, Dixon AL, Fisher E, Glazer NL, Goddard ME, Heard-Costa NL, Hoesel V, Hottenga JJ, Johansson A, Johnson T, Ketkar S, Lamina C, Li S, Moffatt MF, Myers RH, Narisu N, Perry JR, Peters MJ, Preuss M, Ripatti S, Rivadeneira F, Sandholt C, Scott LJ, Timpson NJ, Tyrer JP, van Wingerden S, Watanabe RM, White CC, Wiklund F, Barlassina C, Chasman DI, Cooper MN, Jansson JO, Lawrence RW, Pellikka N, Prokopenko I, Shi J, Thiering E, Alavere H, Alibrandi MT, Almgren P, Arnold AM, Aspelund T, Atwood LD, Balkau B, Balmforth AJ, Bennett AJ, Ben-Shlomo Y, Bergman RN, Bergmann S, Biebermann H, Blakemore AI, Boes T, Bonnycastle LL, Bornstein SR, Brown MJ, Buchanan TA, Busonero F, Campbell H, Cappuccio FP, Cavalcanti-Proenca C, Chen YD, Chen CM, Chines PS, Clarke R, Coin L, Connell J, Day IN, den Heijer M, Duan J, Ebrahim S, Elliott P, Elosua R, Eiriksdottir G, Erdos MR, Eriksson JG, Facheris MF, Felix SB, Fischer-Posovszky P, Folsom AR, Friedrich N, Freimer NB, Fu M, Gaget S, Gejman PV, Geus EJ, Gieger C, Gjesing AP, Goel A, Goyette P, Grallert H, Grassler J, Greenawalt DM, Groves CJ, Gudnason V, Guiducci C, Hartikainen AL, Hassanali N, Hall AS, Havulinna AS, Hayward C, Heath AC, Hengstenberg C, Hicks AA, Hinney A, Hofman A, Homuth G, Hui J, Igl W, Iribarren C, Isomaa B, Jacobs KB, Jarick I, Jewell E, John U, Jorgensen T, Jousilahti P, Jula A, Kaakinen M, Kajantie E, Kaplan LM, Kathiresan S, Kettunen J, Kinnunen L, Knowles JW, Kolcic I, Konig IR, Koskinen S, Kovacs P, Kuusisto J, Kraft P, Kvaloy K, Laitinen J, Lantieri O, Lanzani C, Launer LJ, Lecoeur C, Lehtimaki T, Lettre G, Liu J, Lokki ML, Lorentzon M, Luben RN, Ludwig B, MAGIC; Manunta P, Marek D, Marre M, Martin NG, McArdle WL, McCarthy A, McKnight B, Meitinger T, Melander O, Meyre D, Midthjell K, Montgomery GW, Morken MA, Morris AP, Mulic R, Ngwa JS, Nelis M, Neville MJ, Nyholt DR, O'Donnell CJ, O'Rahilly S, Ong KK, Oostra B, Pare G, Parker AN, Perola M, Pichler I, Pietilainen KH, Platou CG, Polasek O, Pouta A, Rafelt S, Raitakari O, Rayner NW, Ridderstrale M, Rief W, Ruokonen A, Robertson NR, Rzehak P, Salomaa V, Sanders AR, Sandhu MS, Sanna S, Saramies J, Savolainen MJ, Scherag S, Schipf S, Schreiber S, Schunkert H, Silander K, Sinisalo J, Siscovick DS, Smit JH, Soranzo N, Sovio U, Stephens J, Surakka I, Swift AJ, Tammesoo ML, Tardif JC, Teder-Laving M, Teslovich TM, Thompson JR, Thomson B, Tonjes A, Tuomi T, van Meurs JB, van Ommen GJ, Vatin V, Viikari J, Visvikis-Siest S, Vitart V, Vogel CI, Voight BF, Waite LL, Wallaschofski H, Walters GB, Widen E, Wiegand S, Wild SH, Willemsen G, Witte DR, Witteman JC, Xu J, Zhang Q, Zgaga L, Ziegler A, Zitting P, Beilby JP, Farooqi IS, Hebebrand J, Huikuri HV, James AL, Kahonen M, Levinson DF, Macciardi F, Nieminen MS, Ohlsson C, Palmer LJ, Ridker PM, Stumvoll M, Beckmann JS, Boeing H, Boerwinkle E, Boomsma DI, Caulfield MJ, Chanock SJ, Collins FS, Cupples LA, Smith GD, Erdmann J, Froguel P, Gronberg H, Gyllensten U, Hall P, Hansen T, Harris TB, Hattersley AT, Hayes RB, Heinrich J, Hu FB, Hveem K, Illig T, Jarvelin MR, Kaprio J, Karpe F, Khaw KT, Kiemeney LA, Krude H, Laakso M, Lawlor DA, Metspalu A, Munroe PB, Ouwehand WH, Pedersen O, Penninx BW, Peters A, Pramstaller PP, Quertermous T, Reinehr T, Rissanen A, Rudan I, Samani NJ, Schwarz PE, Shuldiner AR, Spector TD, Tuomilehto J, Uda M, Uitterlinden A, Valle TT, Wabitsch M, Waeber G, Wareham NJ, Watkins H, Procardis Consortium. Wilson JF, Wright AF, Zillikens MC, Chatterjee N, McCarroll SA, Purcell S, Schadt EE, Visscher PM, Assimes TL, Borecki IB, Deloukas P, Fox CS, Groop LC, Haritunians T, Hunter DJ, Kaplan RC, Mohlke KL, O'Connell JR, Peltonen L, Schlessinger D, Strachan DP, van Duijn CM, Wichmann HE, Frayling TM, 
Thorsteinsdottir U, Abecasis GR, Barroso I, Boehnke M, Stefansson K, North KE, McCarthy MI, Hirschhorn JN, Ingelsson E, Loos RJ. Association analyses of 249,796 individuals reveal 18 new loci associated with body mass index. Nature Genetics. 2010; 42:937-948. [PubMed: 20935630]

Sun Q, Cornelis MC, Kraft P, Qi L, van Dam RM, Girman CJ, Laurie CC, Mirel DB, Gong H, Sheu CC, Christiani DC, Hunter DJ, Mantzoros CS, Hu FB. Genome-wide association study identifies polymorphisms in LEPR as determinants of plasma soluble leptin receptor levels. Human Molecular Genetics. 2010; 19:1846-1855. [PubMed: 20167575]

Ternouth A, Brandys MK, van der Schouw YT, Hendriks J, Jansson JO, Collier D, Adan RA. Association study of POMC variants with body composition measures and nutrient choice. European Journal of Pharmacolology. 2011; 660:220-225.

Thorleifsson G, Walters GB, Gudbjartsson DF, Steinthorsdottir V, Sulem P, Helgadottir A, Styrkarsdottir U, Gretarsdottir S, Thorlacius S, Jonsdottir I, Jonsdottir T, Olafsdottir EJ, Olafsdottir GH, Jonsson T, Jonsson F, Borch-Johnsen K, Hansen T, Andersen G, Jorgensen T, Lauritzen T, Aben KK, Verbeek AL, Roeleveld N, Kampman E, Yanek LR, Becker LC, Tryggvadottir L, Rafnar T, Becker DM, Gulcher J, Kiemeney LA, Pedersen O, Kong A, Thorsteinsdottir U, Stefansson K. Genome-wide association yields new sequence variants at seven loci that associate with measures of obesity. Nature Genetics. 2009; 41:18-24. [PubMed: 19079260]

Thornton LM, Dellava JE, Root TL, Lichtenstein P, Bulik CM. Anorexia nervosa and generalized anxiety disorder: further explorations of the relation between anxiety and body mass index. Journal of Anxiety Disorders. 2011; 25:727-730. [PubMed: 21514095]

Tozzi F, Thornton LM, Klump KL, Fichter MM, Halmi KA, Kaplan AS, Strober M, Woodside DB, Crow S, Mitchell J, Rotondo A, Mauri M, Cassano G, Keel P, Plotnicov KH, Pollice C, Lilenfeld LR, Berrettini WH, Bulik CM, Kaye WH. Symptom fluctuation in eating disorders: Correlates of diagnostic crossover. American Journal of Psychiatry. 2005; 162:732-740. [PubMed: 15800146]

Xu B, Goulding EH, Zang K, Cepoi D, Cone RD, Jones KR, Tecott LH, Reichardt LF. Brain-derived neurotrophic factor regulates energy balance downstream of melanocortin-4 receptor. Nature Neuroscience. 2003; 6:736-742.

Villarejo C, Fernandez-Aranda F, Jimenez-Murcia S, Penas-Lledo E, Granero R, Penelo E, Tinahones FJ, Sancho C, Vilarrasa N, Montserrat-Gil de Bernabe M, Casanueva FF, Fernandez-Real JM, Fruhbeck G, De la Torre R, Treasure J, Botella C, Menchon JM. Lifetime obesity in patients with eating disorders: Increasing prevalence, clinical and personality correlates. European Eating Disorders Review. 2012; 20:250-254. [PubMed: 22383308]

Vink T, Hinney A, van Elburg AA, van Goozen SH, Sandkuijl LA, Sinke RJ, Herpertz-Dahlmann BM, Hebebrand J, Remschmidt H, van Engeland H, Adan RA. Association between an agouti-related protein gene polymorphism and anorexia nervosa. Molecular Psychiatry. 2001; 6:325-328. [PubMed: 11326303]

Wang F, Gelernter J, Kranzler HR, Zhang H. Identification of POMC exonic variants associated with substance dependence and body mass index. PLoS One. 2012; 7:e45300. [PubMed: 23028917]

Wang K, Zhang H, Bloss CS, Duvvuri V, Kaye W, Schork NJ, Berrettini W, Hakonarson H, Price Foundation Collaborative Group. A genome-wide association study on common SNPs and rare CNVs in anorexia nervosa. Molecular Psychiatry. 2011; 16:949-959. [PubMed: 21079607]

Yilmaz Z, Kaplan AS, Levitan RD, Zai CC, Kennedy JL. Possible association of the DRD4 gene with a history of attention-deficit/hyperactivity disorder in women with bulimia nervosa. International Journal of Eating Disorders. 2012; 45:622-625. [PubMed: 22271608]

Yilmaz Z, Kaplan AS, Zai CC, Levitan RD, Kennedy JL. COMT Val158Met variant and functional haplotypes associated with childhood ADHD history in women with bulimia nervosa. Progress in Neuropsychopharmacology and Biological Psychiatry. 2011; 35:948-952.

J Psychiatr Res. Author manuscript; available in PMC 2015 August 01. 


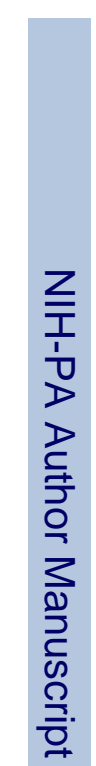

Yilmaz et al.

Page 16

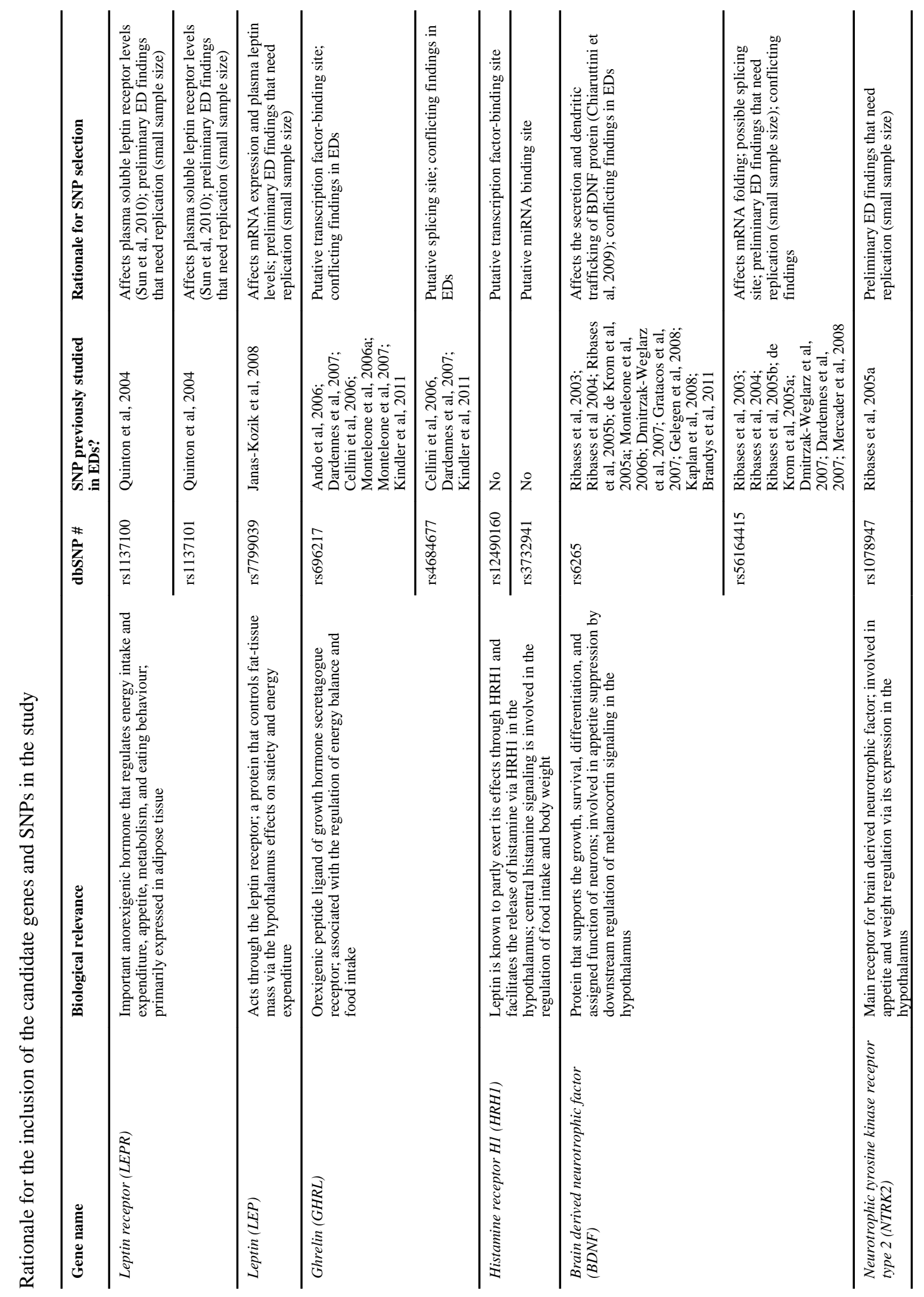

J Psychiatr Res. Author manuscript; available in PMC 2015 August 01. 
Yilmaz et al.

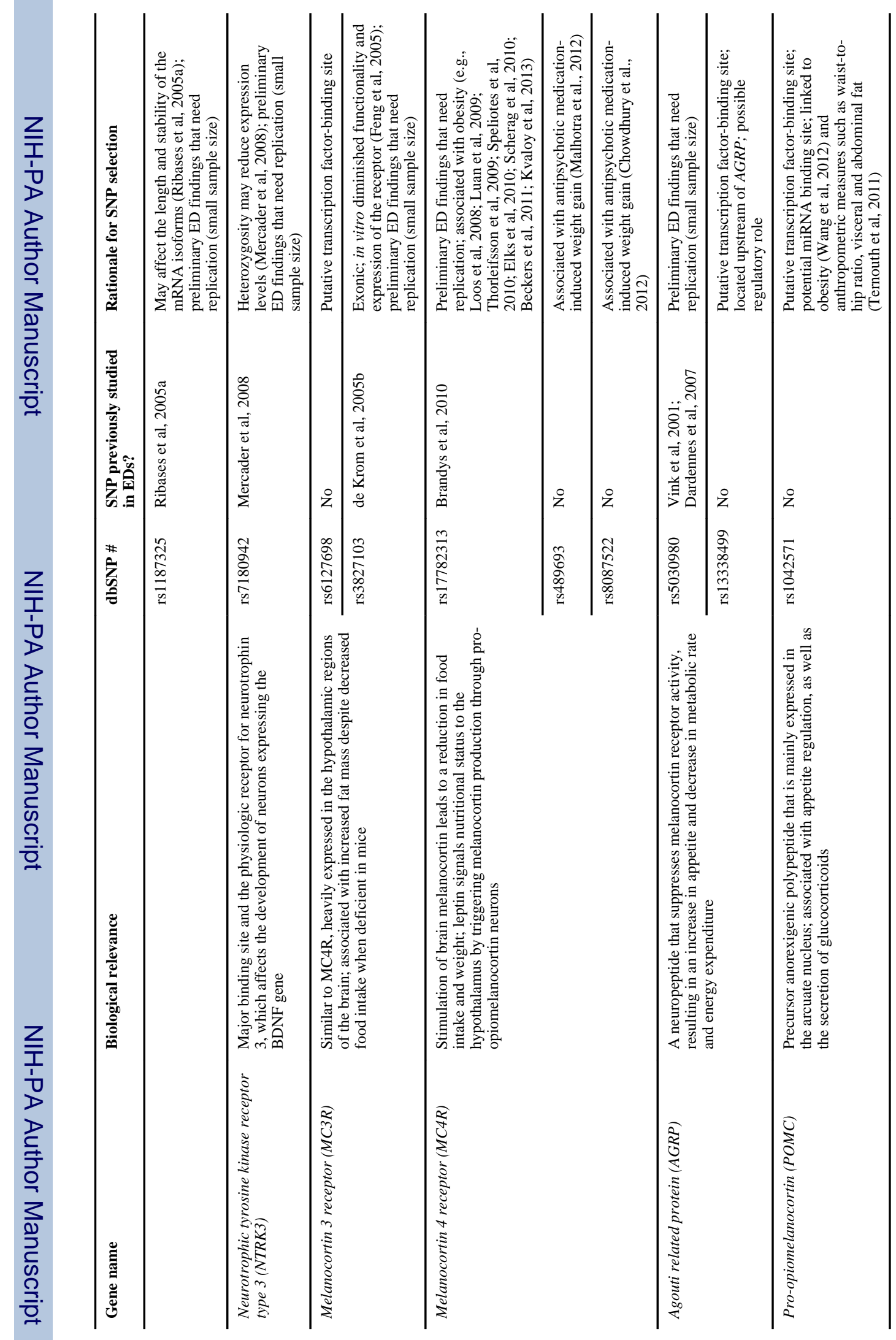

J Psychiatr Res. Author manuscript; available in PMC 2015 August 01. 


\section{Table 2}

Characteristics of $\mathrm{AN}, \mathrm{BN}$, and control participants

\begin{tabular}{lccccc}
\hline & AN $(\mathbf{n}=\mathbf{7 4 5})$ & BN $(\mathbf{n}=\mathbf{2 6 7})$ & Control $(\mathbf{n}=\mathbf{3 2 1})$ & $\boldsymbol{F}$ & $\boldsymbol{p}$ \\
\hline Age $(\text { years })^{a, b}$ & $26.1 \pm 8.5$ & $27.2 \pm 8.3$ & $49.4 \pm 8.8$ & 867.909 & $<0.0001$ \\
CurBMI $\left(\mathrm{kg} / \mathrm{m}^{2}\right)^{c}$ & $18.05 \pm 2.71$ & $23.28 \pm 3.01$ & $23.60 \pm 2.16$ & 671.019 & $<0.0001$ \\
MinBMI $\left(\mathrm{kg} / \mathrm{m}^{2}\right)^{c}$ & $13.82 \pm 1.95$ & $20.09 \pm 1.54$ & - & $-51.198^{d}$ & $<0.0001$ \\
MaxBMI $\left(\mathrm{kg} / \mathrm{m}^{2}\right)^{c}$ & $21.07 \pm 2.42$ & $25.82 \pm 3.06$ & - & $-22.003^{d}$ & $<0.0001$ \\
\hline
\end{tabular}

${ }^{a}$ Age data missing for one $\mathrm{AN}$ and one BN case

${ }^{b}$ Control $>\mathrm{AN}=\mathrm{BN}$

${ }^{c}$ BMI data missing for four BN cases

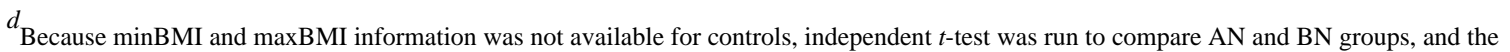
statistic reported here is the $t$-value. 
